\title{
Experimental Assessment of Microbial Effects on Chemical Interactions Between Seafloor Massive Sulfides and Seawater at $4{ }^{\circ} \mathrm{C}$
}

\author{
Shingo Kato, Katsuhiko Suzuki, Takazo Shibuya, Jun-ichiro Ishibashi, \\ Moriya Ohkuma, and Akihiko Yamagishi
}

\begin{abstract}
To assess the effects of microbes on the exchange of $\mathrm{Cu}, \mathrm{Zn}$, and $\mathrm{P}$ between seafloor massive sulfide (SMS) deposits and seawater, we monitored the variation of the concentrations of $\mathrm{Cu}, \mathrm{Zn}$, and $\mathrm{P}$ in the artificial seawater of reaction systems that did or did not also include slabs and microbes originating from an SMS sample at $4{ }^{\circ} \mathrm{C}$ for 71 days. Dissolution of $\mathrm{Cu}$ and $\mathrm{Zn}$ from the slabs was observed when microbes were present or absent. Zinc from the slabs dissolved 1.4-2.3 fold more rapidly when microbes were present. In the presence of slabs and microbes, the rate of removal of $\mathrm{P}$ from the artificial seawater was the sum of the individual removal rates associated with the slabs and microbes. Six bacterial phylotypes including Halomonas and Marinobacter were present at the end of the experiment as shown by PCR-based analysis targeting 16S rRNA genes. These bacteria probably contribute to the release of $\mathrm{Zn}$ from the SMS slab and removal of $\mathrm{P}$ from the artificial seawater. Our results provide further insights into the role(s) of microbes on the geochemical interactions between SMS deposits and seawater.
\end{abstract}

\section{Keywords}

Bacteria $\bullet$ Batch experiment $\bullet$ Elemental cycle $\bullet$ Microbial dissolution $\bullet$ Seafloor massive sulfides

The online version of this chapter (doi:10.1007/978-4-431-54865-2_9) contains supplementary material, which is available to authorized users.

\section{S. Kato}

Japan Collection of Microorganisms, RIKEN BioResource Center,

3-1-1 Koyadai, Tsukuba, Ibaraki 305-0074, Japan

Department of Molecular Biology, Tokyo University of Pharmacy and Life Science, 1432-1 Horinouchi, Hachioji, Tokyo 192-0392, Japan

K. Suzuki

Institute for Research on Earth Evolution (IFREE), Japan Agency for Marine-Earth Science and Technology (JAMSTEC), 2-15 Natsushima, Yokosuka, Kanagawa 237-0061, Japan

Submarine Resources Research Project (SRRP) and Precambrian Ecosystem Laboratory (PEL), Japan Agency for Marine-Earth Science and Technology (JAMSTEC),

2-15 Natsushima, Yokosuka, Kanagawa 237-0061, Japan

\section{T. Shibuya}

Submarine Resources Research Project (SRRP)

and Precambrian Ecosystem Laboratory (PEL), Japan Agency

for Marine-Earth Science and Technology (JAMSTEC),

2-15 Natsushima, Yokosuka, Kanagawa 237-0061, Japan

J.-i. Ishibashi

Department of Earth and Planetary Sciences,

Faculty of Science, Kyushu University, Hakozaki, Higashi-ku,

Fukuoka 812-8581, Japan

\section{Ohkuma}

Japan Collection of Microorganisms, RIKEN BioResource Center, 3-1-1 Koyadai, Tsukuba, Ibaraki 305-0074, Japan

A. Yamagishi $(\bowtie)$

Department of Molecular Biology, Tokyo University of Pharmacy and Life Science, 1432-1 Horinouchi, Hachioji, Tokyo 192-0392, Japan e-mail: yamagish@toyaku.ac.jp 


\subsection{Introduction}

Seafloor massive sulfide (SMS) deposits occur at and around the plate boundaries, e.g., mid-ocean ridges, backarc basins and volcanic arcs (Hannington et al. 2011). These SMS deposits consist of relatively insoluble sulfide minerals, e.g., pyrite $\left(\mathrm{FeS}_{2}\right)$, chalcopyrite $\left(\mathrm{CuFeS}_{2}\right)$, sphalerite $(\mathrm{ZnS})$, and galena $(\mathrm{PbS})$, and also contain trace elements such as $\mathrm{Au}, \mathrm{Ag}$, Co and in some cases, $\mathrm{Ni}$ (Herzig and Hannington 1995). The hydrothermally active and inactive vents of chimney- and mound-shaped SMS deposits are microbe-rich environments, with microbial densities of up to $10^{10}$ cells ( $\mathrm{g}$ sulfide) ${ }^{-1}$ (Kato et al. 2010; Schrenk et al. 2003; Suzuki et al. 2004; Takai and Horikoshi 1999), which are densities comparable with those in soils and animal bowels (Whitman et al. 1998). Dissolved $\mathrm{H}_{2}, \mathrm{H}_{2} \mathrm{~S}, \mathrm{CH}_{4}$ and $\mathrm{Fe}^{2+}$ supplied from hydrothermal fluids in the active sulfide vents serve as energy sources for the microbial communities. Conversely, microbial communities in inactive sulfide vents apparently use metal sulfides as energy sources (Edwards et al. 2003a). An in situ examination of SMS ores with time suggested that sulfide minerals on the seafloor are highly weathered by microbes (Edwards et al. 2003b). However, a quantitative assessment of the elements released from or adsorbed by SMS deposits mediated by microbes had not been done prior to this report.

Considering the high levels of heavy metals in the SMS deposits and the ubiquity of these deposits on the seafloor (Hannington et al. 2011; Herzig and Hannington 1995), an experimental study of the change with time of the SMS components via microbial activity is important to understand how such events impact the oceanic biogeochemical cycles. The concentrations of certain heavy metals, e.g., Fe, Zn, Mn, $\mathrm{Cu}$ and $\mathrm{Ni}$, which are essential for oceanic microbial viability, are extremely small $(<0.1 \mu \mathrm{M})$ in the ocean (Morel and Price 2003; Sohrin and Bruland 2011). The exchange of these heavy metals between seawater and SMS deposits is potentially needed for the maintenance of important oceanic microbial ecosystems.

Here, we report the effects of microbes on the exchanges of elements between SMS samples and seawater by simulating the environmental conditions of deep seafloor (i.e., low temperature, weakly alkaline $\mathrm{pH}$ and a small amount of organic carbon). The goals of this study were (i) to measure the kinetics of the dissolution of certain metals and $\mathrm{P}$ from a recovered SMS sample and (ii) to assess if and how microbial communities affect the kinetics.

\subsection{Materials and Methods}

\subsubsection{Sample Collection}

A portion of massive sulfide ore (sample ID, D903-R1) was collected from a hydrothermal vent field, called the Archaean site $\left(12^{\circ} 56.35^{\prime} \mathrm{N}, 143^{\circ} 38.0^{\prime} \mathrm{E}\right.$; depth, 3,076 m), in the Southern Mariana Trough during the YK05-09 cruise (July to August 2005) by the manned submersible Shinkai 6500 (JAMSTEC, Japan) of the R/V Yokosuka (JAMSTEC, Japan). A bathymetric map of the vent field is shown in a previous report (Kato et al. 2010) and also in Seama et al. (Chap. 17). The SMS sample (Suppl. 9.1a) was washed with filter-sterilized seawater and crushed into fist-sized, subsurface, non-oxidized samples, using an autoclave-sterilized hammer and chisel in a clean box on board. Some of the samples were stored at $-80{ }^{\circ} \mathrm{C}$ in DNA/RNA-free plastic tubes for DNA extraction and the others were stored at $4{ }^{\circ} \mathrm{C}$ for inoculation and mineralogical studies.

\subsubsection{Experimental Medium}

The artificial seawater (ASW) was a modification of that described in the previous report (Jannasch et al. 1996) and contained $20.0 \mathrm{~g} \quad \mathrm{NaCl} ; 3.0 \mathrm{~g} \quad \mathrm{MgCl}_{2} \cdot 6 \mathrm{H}_{2} \mathrm{O} ; \quad 6.0 \mathrm{~g}$ $\mathrm{MgSO}_{4} \cdot 7 \mathrm{H}_{2} \mathrm{O} ; 1.0 \mathrm{~g}\left(\mathrm{NH}_{4}\right)_{2} \mathrm{SO}_{4} ; 0.2 \mathrm{~g} \mathrm{NaHCO}_{3} ; 0.3 \mathrm{~g}$ $\mathrm{CaCl}_{2} \cdot 2 \mathrm{H}_{2} \mathrm{O} ; 0.5 \mathrm{~g} \mathrm{KCl} ; 0.015 \mathrm{~g} \mathrm{KH}_{2} \mathrm{PO}_{4}, 1 \mathrm{~mL}$ of vitamin solution (DSMZ medium 141; http://www.dsmz.de) and $1 \mathrm{~mL}$ of marine trace element solution (DSMZ medium 511), in $1 \mathrm{~L}$ of distilled water. The $\mathrm{pH}$ value of the ASW was 7.3 before autoclaving and 8.1 afterwards. To simulate the low concentrations of organic compounds found in deep seawater, Bacto yeast extract (BD Difco, NJ, USA) was added from an autoclaved stock solution to render the concentration to be $10 \mathrm{mg}$ (corresponding to $3.3 \mathrm{mg}$ of carbon) $\mathrm{L}^{-1}$ in the final medium as described previously (Jannasch et al. 1996).

\subsubsection{Batch Experiments}

A sample of the interior of the SMS was cut into small slabs $(10 \times 10 \times 1 \mathrm{~mm}$; Suppl. 9.1b) using a low speed diamond saw (Struers Minitor, Westlake, OH, USA). Each slab weighed $0.35 \pm 0.05 \mathrm{~g}$. The relative surface area of each slab was $5.72 \pm 0.01 \mathrm{~m}^{2} \mathrm{~g}^{-1}$, as determined by the BET-N $\mathrm{N}_{2}$ method (Seishin Enterprise Co., Ltd., Tokyo, Japan). The slabs were cleaned and sterilized by soaking them in ethanol 
and acetone for $2 \mathrm{~h}$ each according to Edwards et al. (2000) and then dried by flushing with $\mathrm{N}_{2}$ gas at room temperature.

Sterile $250-\mathrm{mL}$ glass culture flasks, each containing $100 \mathrm{~mL}$ of ASW and capped with sponge plugs, were used to contain the incubations. Each flask contained one of the following systems: ASW with slabs and an inoculum; ASW with only slabs; ASW with only an inoculum; only ASW. The contents of all systems were prepared in duplicate, except for the system of only ASW. The inoculum was prepared from a slurry of the mostly oxidized surface of the SMS sample. The cell density of the slurry was $3.62 \pm 0.65 \times 10^{7}$ cells $\mathrm{mL}^{-1}$ (corresponding to $2.22 \pm 0.38 \times 10^{6}$ cells $(\mathrm{g} \text { sulfide })^{-1}$ ) determined by fluorescence microscopy (Kato et al. 2009a). The systems containing slabs and an inoculum are denoted as MC1 and MC2; those with only slabs as $\mathrm{C} 1$ and $\mathrm{C} 2$; those with only an inoculum as M1 and M2; and the negative control, without slabs and an inoculum as $\mathrm{N}$ (i.e., blank test), respectively. $\mathrm{MC} 1, \mathrm{MC} 2, \mathrm{C} 1$ and $\mathrm{C} 2$ each contained 10 slabs. One milliliter of the slurry was added into each of MC1, MC2, M1 and M2. These reaction systems were incubated in a cold room at $4{ }^{\circ} \mathrm{C}$.

An aliquot of $3 \mathrm{~mL}$ ( $1 \mathrm{~mL}$ for direct cell counting and $2 \mathrm{~mL}$ for chemical analyses) was removed from each culture with a sterile disposable syringe at 4, 42, 140, 332, 782, and $1698 \mathrm{~h}$ after the start of the experiment. Before sampling, each medium was gently withdrawn and returned by action of a sterile disposable syringe three times. To determine the number of cells, each sample was filtered through a black polycarbonate filter (pore size, $0.2 \mu \mathrm{m}$; diameter, $13 \mathrm{~mm}$; Advantec, Tokyo, Japan). Each filter was washed twice with ultra-pure water, and then was dried in a sterilized Petri dish and stored at $-20{ }^{\circ} \mathrm{C}$. For the chemical analyses, each sample was filtered through a polycarbonate filter (pore size, $0.2 \mu \mathrm{m}$; diameter, $25 \mathrm{~mm}$; Advantec, Tokyo, Japan), and the filtrates were individually stored in an acid-cleaned 2-mL polypropylene tube. Approximately $300 \mu \mathrm{L}$ of each filtrate was used for the $\mathrm{pH}$ measurement.

At the end of the incubations, a $60 \mathrm{~mL}$ aliquots of each solution was filtered through a polycarbonate filter (pore size, $0.2 \mu \mathrm{m}$; diameter, $13 \mathrm{~mm}$; Advantec, Tokyo, Japan). The filters were stored at $-80{ }^{\circ} \mathrm{C}$ prior to DNA analysis. To remove the microbes that were loosely attached to the slabs, the slabs were gently swished in sterilized Petri dishes containing $30 \mathrm{~mL}$ of ultra-pure water with tweezers. The water was replaced three times. Five slabs from each experiment were stored at $-80{ }^{\circ} \mathrm{C}$ for DNA analysis, and the other five slabs were fixed with $3.7 \%(\mathrm{w} / \mathrm{v})$ formalin at $4{ }^{\circ} \mathrm{C}$ over night and then stored in a $1: 1$ ethanol/phosphatebuffered saline mixture at $-20{ }^{\circ} \mathrm{C}$ until microscopy was performed.

\subsubsection{Chemical Analysis}

To determine the chemical composition of the retrieved SMS sample, $0.1 \mathrm{~g}$ of the slabs was pulverized and decomposed in $\mathrm{HNO}_{3}-\mathrm{HF}-\mathrm{HClO}_{4}$ solution at $90{ }^{\circ} \mathrm{C}$. The solution was evaporated at $90{ }^{\circ} \mathrm{C}$. The residue was dried at $140{ }^{\circ} \mathrm{C}$ and then dissolved in $1.25 \mathrm{~mL} \mathrm{HCl}-\mathrm{HNO}_{3}$ solution at $90^{\circ} \mathrm{C}$. The concentration of each element was determined by multi-channel inductively coupled plasma-optical emission spectrometry (ICP-OES) (SPS5500; SII NanoTechnology, Chiba, Japan). The chemical composition of the sample was 42.9 wt $\% \mathrm{Fe}$ (weight per total weight); 694 ppm Zn; 594 ppm Al; 114 ppm Co; 106 ppm Cu; 97.4 ppm Mg; 72.9 ppm Ba; 46.0 ppm Ca; 32.4 ppm Cd; 30.0 ppm Ni; 23 ppm Na; 9.3 ppm V; 6.90 ppm Rb; 6.80 ppm Sr; 4.0 ppm $\mathrm{Mn}$. We assumed that the remaining solid, which could not be quantified, was sulfur. The uncertainties for the ICP-OES analysis were within $\pm 5 \%$ for $\mathrm{Al}, \mathrm{Ba}, \mathrm{Ca}, \mathrm{Cd}, \mathrm{Cu}, \mathrm{Fe}, \mathrm{Mg}$, $\mathrm{Rb}, \mathrm{Sr}$ and $\mathrm{Zn}$, and approximately $\pm 10 \%$ for $\mathrm{Co}, \mathrm{Mn}, \mathrm{Na}, \mathrm{Ni}$ and $\mathrm{V}$. The detection limit for the aforementioned elements was $<10 \mathrm{ppb}$. Ikehata et al. (Chap. 22) characterized the mineral content of a bulk sample of this SMS of D903-R1, and showed that it was primarily composed of cryptocrystalline pyrite and marcasite with lesser amounts of sphalerite, chalcopyrite, and barite.

The $\mathrm{pH}$ of each system was measured with a TWIN $\mathrm{pH}$ meter (HORIBA, Kyoto, Japan). Concentrations of $\mathrm{Cu}, \mathrm{Zn}$ and $\mathrm{P}$ in the ASW samples with time were measured using the ICP-OES system as described above. The detection limits were $2.25 \mathrm{nmol} \mathrm{L} \mathrm{L}^{-1}$ for $\mathrm{Cu}, 239 \mathrm{nmol} \mathrm{L}^{-1}$ for $\mathrm{P}$, and $5.54 \mathrm{nmol} \mathrm{L}{ }^{-1}$ for $\mathrm{Zn}$. The uncertainty for the $\mathrm{P}$ measurement was $\pm 5 \%$ and that for the $\mathrm{Cu}$ and $\mathrm{Zn}$ measurement was approximately $\pm 10 \%$. We also assessed the concentrations of the other elements that had been detected in the SMS sample; however, no clear temporal trends were observed because of their low concentrations (data not shown). The concentration of each element was corrected for the decrease in the sample volume and the loss of element mass during the sampling using the following equation (Eq. 4 in Wu et al. 2007):

$$
C^{\prime} j, i=\frac{C j, i\left[V_{0}-(j-1) V s\right]+\sum_{h=1}^{j-1} C h, i V s}{V_{0}}
$$

where $C^{\prime}{ }_{\mathrm{j}, \mathrm{i}}$ is the corrected concentration of element $i$ in the $j$ th sample $(\mathrm{j}=1,2 \ldots, 7)$, and $C_{\mathrm{j}, \mathrm{i}}$ is the measured concentration. $V_{O}$ is the initial volume $(0.1 \mathrm{~L}), V_{s}$ is the sample volume $(0.003 \mathrm{~L})$, and the term $\sum_{h=1}^{j-1} C h, i V s$ accounts for the total mass of element $i$ extracted during the samplings. 
Fig. 9.1 Changes in cell density, $\mathrm{pH}$, the concentrations of $\mathrm{Cu}, \mathrm{P}$ and $\mathrm{Zn}$ during the course of the experiments. (a) $\mathrm{pH}$ values. Concentrations of (b) $\mathrm{Cu},(\mathbf{c}) \mathrm{P}$, and (d) Zn. (e) Cell density. Symbol for the systems are shown in the box at the lower right of the figure (see text for details) a
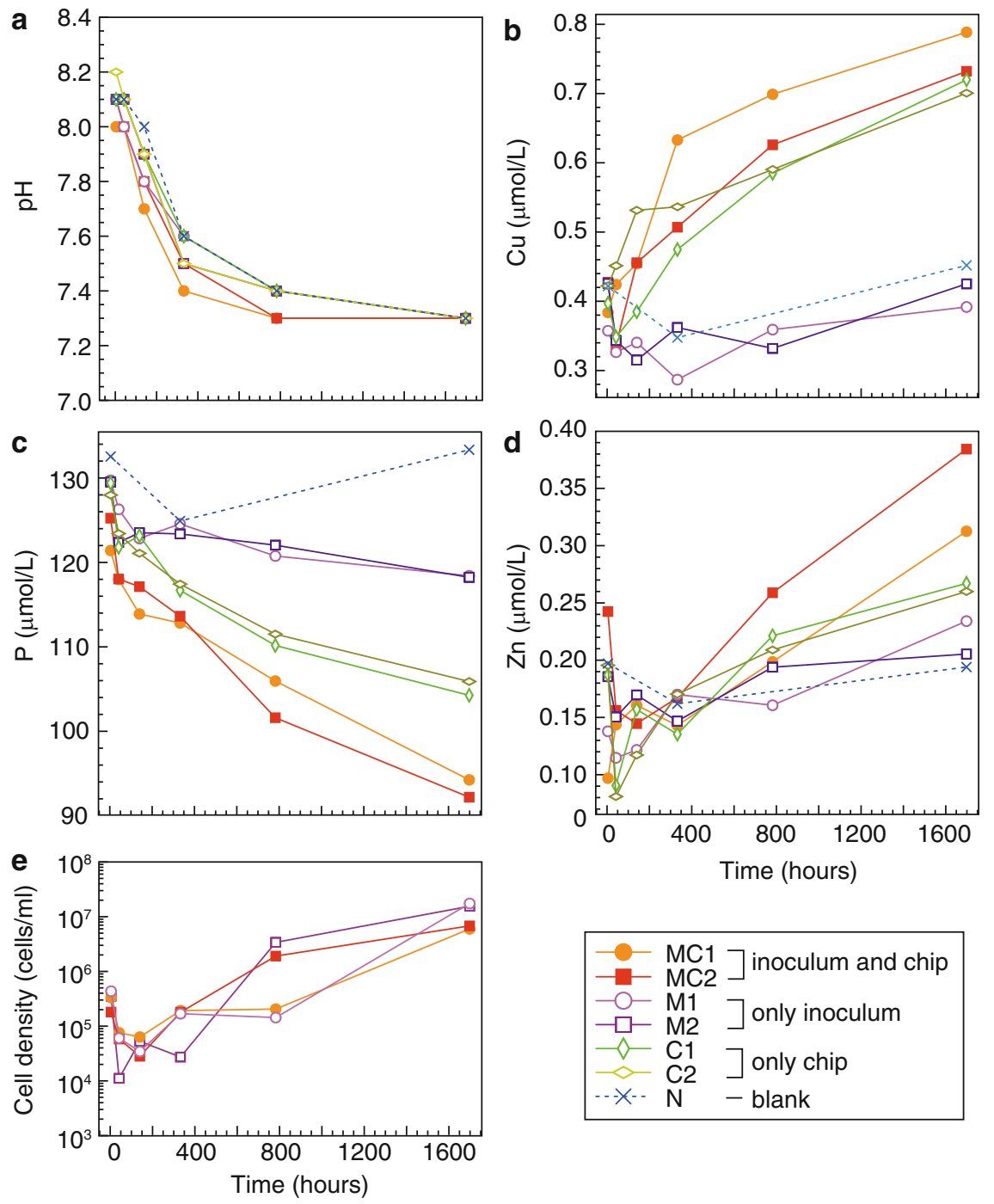

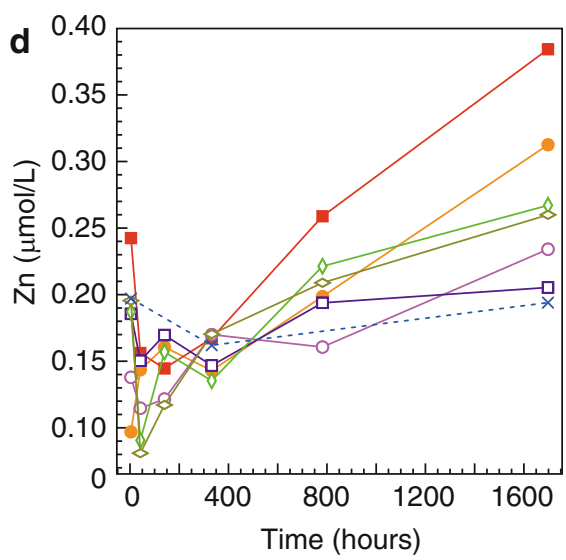

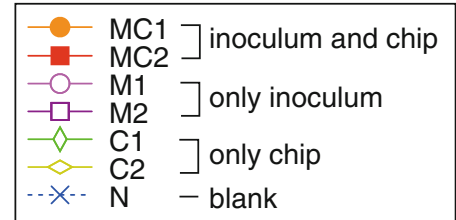

The rate constant $\left(\mathrm{d} C^{\prime} / \mathrm{d} t\right)$ of dissolution for each element was calculated for the $332-1,698 \mathrm{~h}$ period (Suppl. 9.2), a time when the $\mathrm{pH}$ values of the ASW were between 7.3 and 7.5 (Fig. 9.1a and Suppl. 9.3). The release or removal rate $(R)$ of each element to or from the ASW, respectively, was calculated using the corresponding rate constant $\left(\mathrm{d} C^{\prime} / \mathrm{d} t\right)$, the initial fluid volume $\left(V_{0}, 0.1 \mathrm{~L}\right)$, the relative surface area $\left(A, 5.72 \mathrm{~m}^{2} \mathrm{~g}^{-1}\right)$, the total mass of the slabs in each system ( $m, 3.11-3.33 \mathrm{~g})$, and Eq. 5 in Wu et al. (2007):

$$
R=\frac{d C^{\prime} i}{d t} \frac{V_{0}}{A m},
$$

The values for $R$ are listed in Table 9.1.

\subsubsection{S rRNA Gene Clone Library Construction and Phylogenetic Analysis}

The 16S rRNA gene analysis was performed as described (Kato et al. 2009a, b). Partial 16S rRNA genes in extracted genomic DNA were amplified by PCR with the prokaryoteuniversal primer set, Uni515F and Uni1406R (Kato et al. 2009a). The PCR products were cloned and the nucleotide sequences of randomly selected clones were determined. Nucleotide sequences were aligned using ClustalW 2.0.12 (Larkin et al. 2007). Sequences with at least $97 \%$ similarity according to DOTUR (Schloss and Handelsman 2005) were treated as the same phylotype. Maximum-likelihood (ML) trees were constructed using PHYML (Guindon and Gascuel 2003). Bootstrap values were calculated using 100 replicates. 
Table 9.1 Rates of dissolution of $\mathrm{Cu}$ and $\mathrm{Z}$ from the SMS slabs and of removal of $\mathrm{P}$ from the ASW of the samples containing both microbes and slabs $(\mathrm{MC} 1,2)$ microbes, and only slabs $(\mathrm{C} 1,2)$

\begin{tabular}{llll}
\hline & \multicolumn{4}{l}{ Dissolution rate $\left(\mathrm{mol} \mathrm{m}^{-2} \mathrm{~s}^{-1}\right)$} \\
\cline { 2 - 4 } Sample ID & $\mathrm{Cu}$ & $\mathrm{P}$ & $\mathrm{Zn}$ \\
\hline $\mathrm{MC} 1$ & $2.4 . \mathrm{E}-16$ & $-2.0 . \mathrm{E}-14$ & $1.9 . \mathrm{E}-16$ \\
\hline $\mathrm{MC} 2$ & $1.7 . \mathrm{E}-16$ & $-2.2 . \mathrm{E}-14$ & $2.3 . \mathrm{E}-16$ \\
\hline $\mathrm{C} 1$ & $2.5 . \mathrm{E}-16$ & $-1.3 . \mathrm{E}-14$ & $1.3 . \mathrm{E}-16$ \\
$\mathrm{C} 2$ & $1.9 . \mathrm{E}-16$ & $-1.3 . \mathrm{E}-14$ & $1.0 . \mathrm{E}-16$ \\
\hline
\end{tabular}

\subsubsection{Fluorescence Microscopy}

Microbes on the filters and slabs were stained with SYBR Green I. Microscope images were recorded using a fluorescence microscope BX60 (Olympus, Tokyo, Japan) and a cooled CCD camera (Penguin 600CL, Pixera, San Jose, CA, USA). At least 30 fields of the images of each filter and slab were used for cell counting.

\subsubsection{Accession Numbers}

Sequence data were submitted to the DDBJ database under the accession numbers AB600466 to AB600509 for the 16S rRNA genes recovered from the inoculum, and $\mathrm{AB} 600510$ to $\mathrm{AB} 600530$ for the $16 \mathrm{~S}$ rRNA genes recovered at the end of the experiment.

\subsection{Results and Discussion}

\subsubsection{Concentrations and Release/Removal Rates of Elements to/from the ASW Samples}

The initial $\mathrm{pH}$ values of the incubations were between 8.2 and 8.0. They decreased to 7.6-7.4 by $332 \mathrm{~h}$ and finally to 7.3 (Fig. 9.1a) after 1,698 $\mathrm{h}$. The $\mathrm{pH}$ drop may have resulted from dissolution of $\mathrm{CO}_{2}$ from the air because the drop was observed in all samples including $\mathrm{N}$. The change in the concentrations of each element differed during the 4-332$\mathrm{h}$ and 332-1,698-h periods; Fig. 9.1b-d, see also Suppl. 9.3). A $\mathrm{d} C^{\prime} / \mathrm{d} t$ value for each element was calculated for the 332-1,698-h period when the $\mathrm{pH}$ of the systems remained between 7.3 and 7.5 (Fig. 9.1a). Results of the calculation are shown in Suppl. 9.2.

Leaching of $\mathrm{Cu}$ and $\mathrm{Zn}$, which were relatively abundant in the slabs (see above), was observed in the presence and absence of the microbes (Fig. 9.1b, d). In particular, $R$ for $\mathrm{Zn}$ dissolution was greater (1.4-2.3 folds) when microbes were present (Table 9.1). The $\mathrm{d} C^{\prime} / \mathrm{d} t$ values for $\mathrm{Zn}$ were similar for each pair of duplicated samples, i.e., $\mathrm{MC} 1$ and $\mathrm{MC} 2$, and $\mathrm{C} 1$ and C2 (Fig. 9.1d and Suppl. 9.2). In contrast, no differences for the $R$ values of $\mathrm{Cu}$ associated with the $\mathrm{MC} 1$ and $\mathrm{MC} 2$, and $\mathrm{C} 1$ and $\mathrm{C} 2$ samples were observed.

When SMS slabs were present in a reaction system, $\mathrm{P}$ was removed even if microbes were not (Fig. 9.1c). P was also removed in the presence of microbes when slabs were absent (Fig. 9.1c). The $\mathrm{d} C^{\prime} / \mathrm{d} t$ absolute values for $\mathrm{P}$ were greater when only slabs were present $(\mathrm{C} 1$ and $\mathrm{C} 2)$ than when only microbes were present (M1 and M2; Fig. 9.1c, Suppl. 9.2), indicating that the rate of precipitation or adsorption of $\mathrm{P}$ onto the sulfide slabs was faster than the rate of uptake by the microbes. $\mathrm{d} C^{\prime} / \mathrm{d} t$ for $\mathrm{P}$ in the systems that included slabs and microbes (MC1 and $\mathrm{MC} 2$ ) were corresponding to the sums of the values for M1 or M2 and C1 or C2 (Suppl. 9.2).

\subsubsection{Microbial Communities}

The temporal changes in cell densities are shown in Fig. 9.1e, with decreases seen in the MC1, MC2, M1 and M2 systems to $10^{4}-10^{5}$ cells $\mathrm{mL}^{-1}$ at $140 \mathrm{~h}$ and increases up to $10^{6}-10^{7}$ cells $\mathrm{mL}^{-1}$ by $1,698 \mathrm{~h}$. The cell densities in the $\mathrm{C} 1, \mathrm{C} 2$ and $\mathrm{N}$ systems could not be reliably counted by microscopy $\left(<10^{3}\right.$ cells $\left.\mathrm{mL}^{-1}\right)$. Cell colonies were observed on the MC1 and MC2 slabs at the end of the experiment $(6.92 \pm 4.55$ and $5.76 \pm 3.28 \times 10^{5}$ cells cm $^{-2}$, respectively; Suppl. 9.4).

$16 \mathrm{~S}$ rRNA gene clone libraries were constructed from the genomic DNA extracted from the ASW samples and SMS slabs at the end of the experiment. The Inoc library is that from microbes in the original inoculum. The MC1lq, MC2lq, M1lq and M2lq libraries are from microbes in the MC1, MC2, M1 and M2 ASW samples, respectively. The MC1cp and $\mathrm{MC} 2 \mathrm{cp}$ libraries are from microbes on the MC1 and MC2 slabs, respectively. The total numbers of the analyzed clones are 91, 45, 46, 47, 48, 20 and 20 for Inoc, MC1lq, MC1cp, MC2cp, MC2lq, M1lq and M2lq, respectively. 16S rRNA genes were not detected by PCR from the ASW samples and slabs from the $\mathrm{C} 1$ and $\mathrm{C} 2$ systems or from the ASW of the $\mathrm{N}$ system.

The clones in the Inoc library were affiliated with the following taxonomic groups (Fig. 9.2 and Suppl. 9.5): Actinobacteria (5.4\% of the total number of clones), Bacteroidetes (2.2\%), Chloroflexi (1.1\%), Planctomycetes (6.5\%), Alphaproteobacteria (16.3\%), Deltaproteobacteria (2.2\%), Gammaproteobacteria (63.0\%), Zetaproteobacteria $(1.1 \%)$, Verrucomicrobia $(1.1 \%)$ and Euryarchaeota $(1.1 \%)$. Many of the phylotypes in the Inoc library are similar to uncultured environmental clones recovered from the sulfide chimneys of the inactive vents (Kato et al. 2010), from the oceanic basaltic rocks (Santelli et al. 2008) and marine sediments but are distantly related to known species with $<95 \%$ of $16 \mathrm{~S}$ rRNA gene similarity. Phylotypes (the 
a ${ }^{76} \mathrm{AB} 425005$

-AB286179, Rhodanobacter thiooxidans

EF589679, Dokdonella koreensis

AB425011, inactive vent chimney clone YdcGP58

odinoc79

100AB425003, inactive vent chimney clone YdcGP10

inoc07 [+7]

EU134720, tallgrass prarie soil clone $\mathrm{FFCH} 6135$

NC_008340, Alkalilimnicola ehrlichei

- AY360060, Thialkalivibrio thiocyanodenitrificans

- EF455919, Thiohalomonas denitrificans

-DQ789390, Methylonatronum kenyi

oorEU491793, basalt clone EPR3967-O2-Bc46

inoc05

EU491162, basalt clone P9X2b7A04

100FJ497588, basalt clone VS_CL-336

99 inoc47

64 EU491843, basalt clone EPR3965-I2-Bc18

96 AY499670, marine sediment clone Dover279

84 linoc10 [+2]

0 DQ351749, marine sediment clone Belgica2005/10-120-18

AB424967, inactive chimney clone YdcBP05

61 inoc03

-LQ394980, harbor sediment clone VHS-B4-13

GQ349370, deep seawater clone SHAS451

75 FJ497561, basalt clone VS CL-309

-inoc14

AF142798, marine sediment clone ACE-21

79AU491295, basalt clone P9X2b8A08

inoc86

FJ640811, hydrothermal vent chimney clone Ba2

DQ070809, basalt clone 9NBGBact 73

inoc42 [+2]

EU491303, basalt clone P9X2b8D02

AJ564880, Halomonas alkantarctica

AY616755, Halomonas variabilis

MC1cp01 [+39]

AF212202, Halomonas neptunia

MC2cp05 [+33

MC1Iq01 [+35]

M1lq01 [+18]

MC2lg02 [+33]

M2lq01 [+18] inoc25

salt clone EPR4059-B2-Bc1

-basalt clone P0X3b1C11

Thiohalospira alkaliphila

EU491936 seawater clone EPR4055-N3-Bc77

${ }_{55}$ MC1lq02 [+2]



33 AJ319662, Pseudomonas stutzeri

9Q095888, Pseudomonas plecoglossicida

DQ377743, Pseudomonas mandelii

EU246786, plant isolate ROM7-1

74 MČ2cp23 [+3]

89 MC1 1 080

EF028328, Marinobacter salsuginis

EU603452, Marinobacter bryozoorum

EU491065, basalt clone P7X3b4C10

EU491253, basalt clone P9X2b2C11

88 inoc09 $[+18]$

EU491112, basalt clone P9X2b3C07

EU491600, basalt clone EPR3970-MO1A-Bc15

AY225631, hydrothermal sediment clone AT-s2-13

inoc12 [+4]

EU491205, basalt clone P9X2b7F07

inoc19 [+1]

100 DQ351764, marine sediment clone Belgica2005/10-130-19

100 FN396649 marine surface sediment clone s5 O IV 32

FN396649, ma

inoc60 [+6]

5 EU735694, oil contaminated and soil clone SN146

[5-inoc08

56 EF687464, marine microbial mat clone 113B454

linoc88

AB189357, gill symbiont clone JT75-103

oofFJ497318, basalt clone VS_CL-67

inoc75

DQ513013, crustal fluid clone FS140-15B-02

57 GQ348640, deep seawater clone SHAB539

MC1cp24

MC1lq26 [+1]

M2cp11 [+3]

AF384373, Methylophaga alcalica

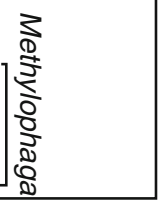

$\underline{0.10}$

Fig. 9.2 Phylogenetic trees for Proteobacteria. The ML trees for (a) Gammaproteobacteria and (b) Deltaproteobacteria, Alphaproteobacteria and Zetaproteobacteria were inferred using 753 and 752 homologous positions in the alignment dataset, respectively. Mariprofundus ferrooxydans (EF493243) or Halomonas aquamarina b

100.MC1lq12 [+1]

EU880514, Thalasso

100 EU770407, deep sea sediment clone 47

AY922187, whalefall clone 131598

64 EU236398, marine sponge Hg92C9

74 Inoc56 [+1]

EU851414, deep seawater clone P33

1 11917 AF544015, Parvularcula bermudensi

56 EU491808, basalt clone EPR3967-O2-Bc62

99 Inoc67 [+1]

EU491551, basalt clone EPR4059-B2-Bc49

100 FJ 497547, basalt clone clone VS CL-295

Inoc02

74 EU491590, basalt clone EPR4059-B2-Bc9

100 Inoc24

EU491857, basalt clone EPR3965-I2-Bc38

73EU491804, basalt clone EPR3967-O2-Bc58

91. Inoc53

AM292386, marine sediment clone $\mathrm{DH}-1602$

83. AB424830, inactive vent chimney PltcBP28

Inoc16

FJ497464, basalt clone VS CL-215

EF092167, Axinella corrugata clone AC3_A11

Inoc93

DQ925895, hydrothermal chimney clone 21B4

EF 092190, Axinella corrugata clone Ax26_FX

FJ497586, basalt clone VS_CL-334

Inoc15

-AF353236, marine clone Arctic97A-7

GQ348236, deep seawater clone SGSX805

Y Y10109, Magnetospirillum gryphiswaldense

$100-1$ AB424836, inactive vent chimney PItcBP41

Inoc23 [+3]

EEU287396, arctic surface sediment S26-96

00 65 D665839, Nisaea denitrificans

DQ097519, Delongia marina

IInoc71

[DQ69090, marine clone DPC014

100 AF082791, Hyphomonas johnsonii

97/AY226291, hypersaline anoxic basin clone DBBB-39

54 Inoc13

96-AJ296568, mill tailing clone GR-296.II.52

00 EU574654, hydrothermal vent mat clone 1WB 25

L35504, Nitrospina gracilis

67 EU491803, basalt clone EPR3967-O2-Bc57 oo. Inoc31

58F424236, marine sediment clone MERTZ OCM 225 88 AF418174, Desulfovibrio baarsii

-AF382397, Anaeromyxobacter dehalogenans

-U28172, Desulfuromonas palmitatis

-AY653551, Geobacter psychrophilus

68 U15116, hydrothermal vent clone PVB_OTU_4

100 Inoc38

70 DQ832638, hydrothermal vent mat clone CM2

EF493243, Mariprofundus ferrooxydans

00 AB284833, hydrothermal fluid clone Papm3BL54

${ }_{100}$ AB284832, hydrothermal fluid clone Papm3BL26

0.10

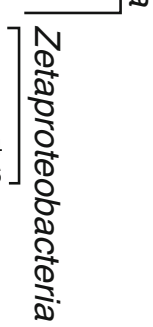

(AJ306888) were used as the out groups for each tree (data not shown). Bootstrap values $(>50 \%)$ based on 100 replicates are shown at the branch points. The scale bar represents 0.1 nucleotide substitutions per sequence position. The clone numbers are shown in bold type. The numbers that follow in brackets indicate the number of detected clones 
Table 9.2 Number of PCR clones detected in the ASW samples and slabs at the end of the experiments

\begin{tabular}{|c|c|c|c|c|c|c|}
\hline & \multicolumn{6}{|c|}{ Sample ID } \\
\hline & $\mathrm{MC} 1 \mathrm{cp}$ & MC1lq & $\mathrm{MC} 2 \mathrm{cp}$ & MC2lq & M1lq & M2lq \\
\hline \multicolumn{7}{|l|}{ Bacteroidetes } \\
\hline \multicolumn{7}{|l|}{ Sphingobacteria } \\
\hline Algoriphagus & $1(2.2)$ & $3(6.5)$ & $5(10.6)$ & $9(18.8)$ & $1(5.0)$ & $1(5.0)$ \\
\hline \multicolumn{7}{|l|}{ Proteobacteria } \\
\hline \multicolumn{7}{|c|}{ Alphaproteobacteria } \\
\hline Thalassospira & & $2(4.3)$ & & $3(6.3)$ & & \\
\hline \multicolumn{7}{|c|}{ Gammaproteobacteria } \\
\hline Halomonas & $40(88.9)$ & $36(78.3)$ & $34(72.3)$ & $34(70.8)$ & $18(90.0)$ & $17(85.0)$ \\
\hline Marinobacter & $2(4.4)$ & $2(4.3)$ & $3(6.4)$ & $1(2.1)$ & & \\
\hline Methylophaga & $1(2.2)$ & $2(4.3)$ & $4(8.5)$ & & & $2(10.0)$ \\
\hline Pseudomonas & $1(2.2)$ & $1(2.2)$ & $1(2.1)$ & $1(2.1)$ & $1(5.0)$ & \\
\hline Total & $45(100)$ & $46(100)$ & $47(100)$ & $48(100)$ & $20(100)$ & $20(100)$ \\
\hline
\end{tabular}

Numbers in parentheses are the percentage of the clones in each taxon

representative clones: inoc38 and 51) related to Mariprofundus ferrooxydans (95\% similarity) of Zetaproteobacteria and Ferrimicrobium acidiphilum (89\% similarity) of Actinobacteria, which are iron-oxidizing bacteria, were also detected in the Inoc library. In contrast to the great diversity of the microbial community in the original inoculum, only six phylotypes were detected at the end of the experiment (Table 9.2). These phylotypes were completely different from those in the Inoc library (Fig. 9.2 and Suppl. 9.5), probably because the original phylotypes had been out-competed during the incubation periods.

\subsubsection{Microbial Effects on Chemical Interaction on Sulfide Deposits}

The bacterial species, e.g., Halomonas and Marinobacter, found at the end of the experiment should be minor constituents of the microbial community of the in situ SMS deposits because they were not detected in the original inoculum. The species present at the end of the experiment were probably selected by the experimental conditions. These species may have influenced the release of $\mathrm{Zn}$ and removal of $\mathrm{P}$. Remarkably, these species have been detected in SMS samples in various deep-sea fields (Edwards et al. 2003b; Kaye et al. 2010; Rogers et al. 2003), suggesting that they may play a role in the release of $\mathrm{Zn}$ and removal of $\mathrm{P}$ in situ.

Our results suggest that microbial action accelerated $\mathrm{Zn}$ dissolution from the SMS slabs. Iron-oxidizing bacteria convert $\mathrm{Fe}^{2+}$ to $\mathrm{Fe}^{3+}$, such that $\mathrm{Fe}^{3+}$ can then react with sphalerite $(\mathrm{ZnS})$ as oxidants to release $\mathrm{Zn}^{2+}$ (Fowler and Crundwell 1999) as follows:

$$
\begin{gathered}
4 \mathrm{Fe}^{2+}+\mathrm{O}_{2}+4 \mathrm{H}^{+} \rightarrow 4 \mathrm{Fe}^{3+}+2 \mathrm{H}_{2} \mathrm{O} \\
\mathrm{ZnS}+2 \mathrm{Fe}^{3+} \rightarrow \mathrm{Zn}^{2+}+2 \mathrm{Fe}^{2+}+\mathrm{S}
\end{gathered}
$$

In fact, the SMS samples contain sphalerite (Ikehata et al. Chap. 22). The genus Marinobacter includes an ironoxidizing bacterium that has been isolated from an SMS sample (Edwards et al. 2003c). In addition, local acidification on the sulfide slabs by microbes might also have accelerated the dissolution of $\mathrm{Zn}$ in our systems, similar to that of silicate dissolution by Arthrobacter sp. (Liermann et al. 2000). The genus Halomonas includes acid-producing bacteria (Sanchez-Porro et al. 2010). Our 16S rRNA gene analysis indicates that the Marinobacter sp. and Halomonas sp. were attached to the slabs. Thus, the activity of these species likely contributed to the acceleration of the $\mathrm{Zn}$ dissolution from the sulfide slabs. In contrast to the dissolution of $\mathrm{Zn}$, we did not observe a significantly accelerated $\mathrm{Cu}$ dissolution from the slabs.

$\mathrm{P}$ was removed from the ASW when microbes and/or slabs were present. Microbes use $\mathrm{P}$ as a nutrient. An increase in cell numbers with time was observed in the systems to which the inoculum had been added (Fig. 9.1e). Other reports have suggested that $\mathrm{P}$ is removed from seawater by adsorption onto the solid surfaces of sediments and rocks (Berner 1973; Wheat et al. 1996), which is consistent with our observation that $\mathrm{P}$ is removed from the systems containing only slabs (Fig. 9.1c). Notably, $\mathrm{P}$ was removed from the ASW more rapidly when only slabs were present, than when only microbes were present (Fig. 9.1c); however, rate of $\mathrm{P}$ removal from seawater on actual environments by SMS deposits and by microbes in situ should fluctuate according to the in situ physicochemical conditions and the degree of microbial activity.

\subsubsection{Conclusion and Perspective}

In the present study, we conducted batch experiments with and without the SMS samples and microbes at $4{ }^{\circ} \mathrm{C}$ and monitored certain chemical and microbial changes in the 
reaction systems for 71 days. The dissolution rate of $\mathrm{Zn}$ from the SMS slabs was faster when microbes were present than in the absence of microbes, suggesting that the microbes accelerated $\mathrm{Zn}$ dissolution. Removal of $\mathrm{P}$ from the ASW was observed when microbes were present or absent and slabs were present. Our results should lead to a better understanding of the roles played by SMS deposits with microbes in the oceanic biogeochemical cycles.

Between 1 and 90 million-tons of the SMS deposits are estimated to be present in each hydrothermal field (Herzig and Hannington 1995). Given that the total amount of SMS deposits on the seafloor and their relative surface areas are approximately 100 million-tons and $6 \mathrm{~m}^{2} \mathrm{~g}^{-1}$, respectively, the flux of $\mathrm{P}$ adsorbed onto SMS deposits can be calculated as $4 \times 10^{8} \mathrm{~mol} \mathrm{year}^{-1}$ with the use of the averaged $R$ value from Table 9.1 for the MC systems. This value is approximately one-hundredth of the input of $\mathrm{P}$ yearly into the oceans from rivers $\left(3 \times 10^{10} \mathrm{~mol} \mathrm{year}^{-1}\right)$ (Elderfield and Schultz 1996), which suggests that adsorption of P by SMS deposits with microbes helps control the levels of oceanic P. Similar calculations suggest that the yearly release of $\mathrm{Zn}$ from the SMS deposits (approx. $\sim 2 \times 10^{6} \mathrm{~mol} \mathrm{year}^{-1}$ ) should be much smaller than that from rivers (approx. $\sim 10^{10} \mathrm{~mol} \mathrm{year}^{-1}$ ) (Elderfield and Schultz 1996). Our estimates are rough approximations because the total amount of SMS deposits are probably underestimated and the necessary in situ microbial and physicochemical information has not been adequately delineated. Additional investigations are needed to more accurately calculate the fluxes of elements associated with SMS deposits.

\begin{abstract}
Acknowledgements We thank Dr. Kenji Shimizu (IFREE, JAMSTEC) for preparing the SMS slabs. We thank the crew of the R/ V Yokosuka and the operation team of Shinkai 6500 for their cooperation in sample collection. We are also grateful to the scientists of the YK05-09 cruise and to the members of Project TAIGA (Trans-crustal Advection and In-situ biogeochemical processes of Global sub-seafloor Aquifer) for providing valuable samples and for helpful discussions. Furthermore, we are grateful to two anonymous reviewers for valuable comments and suggestions. This research was funded by the Ministry of Education, Culture, Science and Technology (MEXT), Japan, through a Grant-in-Aid for Scientific Research on Innovative Areas (Project TAIGA, \#20109006) and partly by the RIKEN Special Postdoctoral Researchers Program.
\end{abstract}

Open Access This chapter is distributed under the terms of the Creative Commons Attribution Noncommercial License, which permits any noncommercial use, distribution, and reproduction in any medium, provided the original author(s) and source are credited.

\section{References}

Berner RA (1973) Phosphate removal from sea water by adsorption on volcanogenic ferric oxides. Earth Planet Sci Lett 18(1):77-86

Edwards KJ, Bond PL, Banfield JF (2000) Characteristics of attachment and growth of thiobacillus caldus on sulphide minerals: a chemotactic response to sulphur minerals? Environ Microbiol 2 (3):324-332

Edwards KJ, Bach W, Rogers DR (2003a) Geomicrobiology of the ocean crust: a role for chemoautotrophic fe-bacteria. Biol Bull 204 (2): $180-185$

Edwards KJ, McCollom TM, Konishi H, Buseck PR (2003b) Seafloor bioalteration of sulfide minerals: results from in situ incubation studies. Geochim Cosmochim Acta 67(15):2843-2856

Edwards KJ, Rogers DR, Wirsen CO, McCollom TM (2003c) Isolation and characterization of novel psychrophilic, neutrophilic, $\mathrm{Fe}$ oxidizing, chemolithoautotrophic $\alpha$ - and $\gamma$-proteobacteria from the deep sea. Appl Environ Microbiol 69(5):2906-2913

Elderfield H, Schultz A (1996) Mid-ocean ridge hydrothermal fluxes and the chemical composition of the ocean. Annu Rev Earth Planet Sci 24(1):191-224. doi:10.1146/annurev.earth.24.1.191

Fowler TA, Crundwell FK (1999) Leaching of zinc sulfide by thiobacillus ferrooxidans: bacterial oxidation of the sulfur product layer increases the rate of zinc sulfide dissolution at high concentrations of ferrous ions. Appl Environ Microbiol 65(12):5285-5292

Guindon S, Gascuel O (2003) A simple, fast, and accurate algorithm to estimate large phylogenies by maximum likelihood. Syst Biol 52(5):696-704

Hannington M, Jamieson J, Monecke T, Petersen S, Beaulieu S (2011) The abundance of seafloor massive sulfide deposits. Geology 39(12):1155-1158. doi:10.1130/g32468.1

Herzig PM, Hannington MD (1995) Polymetallic massive sulfides at the modern seafloor a review. Ore Geol Rev 10(2):95-115

Jannasch HW, Wirsen CO, Doherty KW (1996) A pressurized chemostat for the study of marine barophilic and oligotrophic bacteria. Appl Environ Microbiol 62(5):1593-1596

Kato S, Kobayashi C, Kakegawa T, Yamagishi A (2009a) Microbial communities in iron-silica-rich microbial mats at deep-sea hydrothermal fields of the Southern Mariana Trough. Environ Microbiol 11(8):2094-2111

Kato S, Yanagawa K, Sunamura M, Takano Y, Ishibashi J, Kakegawa T, Utsumi M, Yamanaka T, Toki T, Noguchi T, Kobayashi K, Moroi A, Kimura H, Kawarabayasi Y, Marumo K, Urabe T, Yamagishi A (2009b) Abundance of Zetaproteobacteria within crustal fluids in back-arc hydrothermal fields of the Southern Mariana Trough. Environ Microbiol 11(12):3210-3222

Kato S, Takano Y, Kakegawa T, Oba H, Inoue K, Kobayashi C, Utsumi M, Marumo K, Kobayashi K, Ito Y, Ishibashi J, Yamagishi A (2010) Biogeography and biodiversity in sulfide structures of active and inactive vents at deep-sea hydrothermal fields of the Southern Mariana Trough. Appl Environ Microbiol 76(9):2968-2979. doi:10.1128/aem.00478-10

Kaye JZ, Sylvan JB, Edwards KJ, Baross JA (2010) Halomonas and Marinobacter ecotypes from hydrothermal vent, subseafloor, and deep-sea environments. FEMS Microbiol Ecol 75(1):123-133. doi:10.1111/j.1574-6941.2010.00984.x

Larkin MA, Blackshields G, Brown NP, Chenna R, McGettigan PA, McWilliam H, Valentin F, Wallace IM, Wilm A, Lopez R, Thompson JD, Gibson TJ, Higgins DG (2007) Clustal W and Clustal X version 2.0. Bioinformatics 23(21):2947-2948. doi:10.1093/bioinformatics/btm404

Liermann LJ, Barnes AS, Kalinowski BE, Zhou X, Brantley SL (2000) Microenvironments of $\mathrm{pH}$ in biofilms grown on dissolving silicate surfaces. Chem Geol 171(1-2):1-16

Morel FMM, Price NM (2003) The biogeochemical cycles of trace metals in the oceans. Science 300(5621):944-947. doi:10.1126/ science. 1083545

Rogers DR, Santelli CM, Edwards KJ (2003) Geomicrobiology of deep-sea deposits: Estimating community diversity from lowtemperature seafloor rocks and minerals. Geobiology 1 (2):109-117. doi:10.1046/j.1472-4669.2003.00009.x 
Sanchez-Porro C, Kaur B, Mann H, Ventosa A (2010) Halomonas titanicae sp. nov., a halophilic bacterium isolated from the RMS Titanic. Int J Syst Evol Microbiol 60(12):2768-2774. doi:10.1099/ijs.0.020628-0

Santelli CM, Orcutt BN, Banning E, Bach W, Moyer CL, Sogin ML, Staudigel H, Edwards KJ (2008) Abundance and diversity of microbial life in ocean crust. Nature 453(7195):653-656

Schloss PD, Handelsman J (2005) Introducing DOTUR, a computer program for defining operational taxonomic units and estimating species richness. Appl Environ Microbiol 71(3):1501-1506

Schrenk MO, Kelley DS, Delaney JR, Baross JA (2003) Incidence and diversity of microorganisms within the walls of an active deepsea sulfide chimney. Appl Environ Microbiol 69(6):3580-3592

Sohrin Y, Bruland KW (2011) Global status of trace elements in the ocean. TrAC Trends Anal Chem 30(8):1291-1307
Suzuki Y, Inagaki F, Takai K, Nealson KH, Horikoshi K (2004) Microbial diversity in inactive chimney structures from deep-sea hydrothermal systems. Microb Ecol 47(2):186-196

Takai K, Horikoshi K (1999) Genetic diversity of archaea in deep-sea hydrothermal vent environments. Genetics 152 (4): 1285-1297

Wheat CG, Feely RA, Mottl MJ (1996) Phosphate removal by oceanic hydrothermal processes: an update of the phosphorus budget in the oceans. Geochim Cosmochim Acta 60(19):3593-3608

Whitman WB, Coleman DC, Wiebe WJ (1998) Prokaryotes: the unseen majority. Proc Natl Acad Sci U S A 95:6578-6583

Wu L, Jacobson AD, Chen H-C, Hausner M (2007) Characterization of elemental release during microbe-basalt interactions at $\mathrm{T}=28^{\circ} \mathrm{C}$. Geochim Cosmochim Acta 71(9):2224-2239 